\title{
Implementation of an Integrated Health Risk Assessment Coupled with Spatial Interpolation and Source Apportionment: A Case Study of Soil Heavy Metals, China
}

\author{
Fangfang Miao \\ North China Electric Power University \\ Yimei Zhang ( $\nabla$ mist1218@tom.com ) \\ North China Electric Power University \\ Yu Li \\ North China Electric Power University \\ Qinglu Fang \\ North China Electric Power University \\ Yinzhuang Zhou \\ Capital Normal University
}

\section{Research Article}

Keywords: Soil heavy metals, Spatial interpolation, Global data optimization, Quantitative source apportionment, Source-identified health risk

Posted Date: September 3rd, 2021

DOl: https://doi.org/10.21203/rs.3.rs-850896/v1

License: (c) (i) This work is licensed under a Creative Commons Attribution 4.0 International License.

Read Full License 
1 Implementation of an integrated health risk assessment coupled with spatial 2 interpolation and source apportionment: A case study of soil heavy metals, China

${ }^{a}$ MOE Key Laboratory of Resources and Environmental System Optimization, College of Environmental Science and Engineering, North China Electric Power University, Beijing, 102206, China

${ }^{\mathrm{b}}$ Laboratory of Environmental Remediation and Functional Material, Suzhou Research Academy of North China Electric Power University, Suzhou, Jiangsu, 215213, China

${ }^{\mathrm{c}}$ Key Laboratory for Northern Urban Agriculture of Ministry of Agriculture and Rural Affairs, College of Bioscience and Resources Environment, Beijing University of Agriculture, Beijing, 102206, China

${ }^{\mathrm{d}}$ Department of Chemistry, Capital Normal University, Beijing 100048, PR China

E-mail: zhangym@ncepu.edu.cn; Fax:86-0512-67332655; Tel: 86-0512-67332668

Address: Suzhou Research Academy of North China Electric Power University, Suzhou, Jiangsu, 215123, P.R.China

\section{Abstract}

However, the lack of correlation of risk assessment between source identification of heavy metal led to unclear

direction of source governance. A methodology was established by combining source apportionment of human health

risks with ecological enrichment to characterize source-identified risks of heavy metals based on Ordinary kriging interplotation. Principal component analysis (PCA) and positive matrix factorization (PMF) model were used to identify and classify potential sources of heavy metals synthetically. The integrated results were incorporated into the health risk model to evaluate potential non-carcinogenic and carcinogenic risk of soil heavy metals. A case study was conducted in Suzhou city of China. The results showed that concentrations of $\mathrm{Cd}$ and $\mathrm{Hg}$ were highly above the background values, accounting for percentages of $239.6 \%$ and $415.9 \%$ above background values, respectively. The 
agriculture activities. The Non-cancer health risk index for children and adults was 1.08 and 1.00 respectively. The cancer health risk was 3.67E-03 for children and 3.97E-04 for adults. Cr originated from indutriy activities, accounting for $29.5 \%$ of total heavy metals, and constituted the largest carcinogenic impact on the population. This study provided a new insight for the treatment of mutil-sources of soil heavy metal pollution and also some reference value for the improvement of the risk assessment system.

\section{Keywords:}

Soil heavy metals; Spatial interpolation; Global data optimization; Quantitative source apportionment;

\section{Source-identified health risk}

beings live on (Liang et al., 2017; Järup, 2003). However, with the increasing agricultural production, industrial activities and human activities, great pressure was put on the soil quality continually, resulting in direct soil pollution, especially soil heavy metal pollution (Ihedioha et al., 2017; Salmani-Ghabeshi et al., 2016; Luo et al., 2011). The heavy metal pollutants in soil mainly include $\mathrm{Hg}, \mathrm{Cd}, \mathrm{Pb}, \mathrm{Cr}, \mathrm{Cu}, \mathrm{Ni}, \mathrm{Co}$, Sn and the metal-like As. Distinc from other pollution, heavy metal pollution was not easy to be leached with water and decomposed by microorganism in soil

(Xie et al., 2016; Papa et al., 2010). There were four main ways in which heavy metals entered the soil: atmospheric deposition (natural and man-made), fertilizers containing metal impurities, industrial emission, and irrigation of contaminated water (Luo et al., 2015; Liu et al., 2017). Afterwards heavy metals entered the food chain through accumulation in plants and have obvious biological enrichment, posing risks to the ecosystem and human health (Han et al., 2006; Kurt-Karakus, 2012). In addition, heavy metal was often tightly bound to soil solids, and even small increases in the current concentration of heavy metals can have potentially adverse effects on soil quality (Islam et al., 2017; Noll, 2002). Due to the increasingly serious soil pollution, it was important to predict the accumulation trend of heavy metals in soil and understand the risk level of heavy metal pollution (Teng et al., 2010). Therefore, it 
was of far-reaching significance to effectively assess the pollution situation, including potential local ecological risks,

identify potential pollution sources, so as to provide information for soil pollution control (CSC, 2016). So far, many

research groups had worked on the investigation of soil pollution (Couto et al., 2018; Mendoza et al., 2017). However,

most of these studies focus on agricultural pollution or water pollution, and there were comparatively few studies on

the soil pollution of abandoned dye factory (Gholizadeh et al., 2019; Xiao et al., 2019; Mohammadi et al., 2020;).

The soil environment of many factories in the whole country of China was not optimistic and was serious in some areas (Chen et al., 2015). To strengthen environmental management, a series of policies were implemented to focus on seriously polluted enterprises and force the closure of the small and heavily polluted factories. The pollution of some heavy metals in the soil left by such closed enterprises deserved our attention. The site of the original production enterprises in the process of development, especially dyeing factories, may be polluted by heavy metals (Mao et al., 2019). Pollutants often existed in waste water and waste residue which may leak through the staging point, migration of elution infiltration into the soil and rivers (Wcislo et al., 2016). Therefore, the original location and the surroundings may be polluted, leading great harm to the ecological environment and human health. So it was necessary to scrap the dye factory for soil pollution characteristics, ecology and human health risk assessment.

Scholars at home and abroad had carried out extensive studies on soil pollution characteristics and human health risk assessment in the surrounding areas such as coal production, transportation and storage, as well as coal-fired power plants, but there were few reports on the investigation and assessment of soil pollution in abandoned dyestuff factories (Jia et al., 2015). Therefore, it was necessary to further study the soil pollution in the abandoned dye factory area in order to make better use of the site and provide reference for the site remediation in the next step.

To reduce the hazard of soil heavy metals, source apportionment can be an effective tool to quantify the pollution sources of heavy metals in polluted sites (Jiang et al., 2019; Guan et al., 2018). Even if there were some studies on the classification of pollution sources of soil heavy metals. Studies organically combined the contribution rate of source analysis with human health risk had also been reported, but few about systematic relevance between them 
(Xiao et al., 2019). In order to better understand the pollution level of heavy metals in soil, spatial interpolation method was often used to obtain the concentration distribution of heavy metals in soil. In addition, enrichment factor (EF) was also calculated to obtain the ecological enrichment information of soil pollution (Tian et al., 2017; Nazzal et al., 2016). It was essential to find out further information about the characteristic distribution, pollution sources and environmental risks of heavy metals in polluted sites (Jiang et al., 2017; Niu et al., 2020). Identifying potential pollution sources of heavy metals was the basic premise for designing targeted pollution control measures. Although source apportionment and environmental risk assessment of heavy metal pollution had been carried out in many studies and the study of source-specific health risk and potential ecological risk based on the contribution rate of source analysis was also been reported (Peng et al., 2016). However, they mainly focused on the heavy metals from atmospheric and urban river-lake system (Tapia-Gatica et al.,2020; Li et al., 2020). Metal pollution from abandoned dye factories had been scarely reported, let alone the overall impact of health risks on the study area. Positive matrix factorization (PMF) and Principal component analysis (PCA) was widely used for pollution source analysis in various media such as the atmosphere, hydrosphere and soil sphere (Liang et al., 2017a; Lang et al., 2015). It can be applied to apportion the potential sources of heavy metals (Norris et al., 2014). Compared with traditional multivariate statistical analysis methods, PMF was able to deal with the measurement uncertainty inherent in environmental data (Paatero and Tapper, 1994; Lv and Liu, 2019). Quantitative source analysis and its contribution research were helpful to identify the main pollution sources and quantified their contribution rate (Yang et al., 2019; Kumar et al., 2019).In addition, the city we studied, Suzhou, as a developed industrial area, the closure of polluting factories will inevitably leaded to the intensification of other human activities driven by the economy (Zhang et al., 2018). Therefore, there was the need to conduct the first detailed evaluation of the total effects of health risks on soil heavy metals associated with the areas related to a dye factory in the southeast of Suzhou by using multivariate statistical and spatial analysis methods. 
data in the sampling sites with reference to the Soil Guide of China (National Environmental Protection Agency,

1995);(ii) Multivariate statistics and spatial distribution of ecological enrichment for analyzing the ecological pollution levels; (iii) identification of potential sources of soil heavy metals pollution and quantification of the proportions of various sources through combination of PCA and PMF models; (iv) Calculation of source-contributed human health risk index; (v) total effects of health risks on soil heavy metals. This study can provide reference for soil remediation and protection design in the study area and also reference for policy formulation and protection research on soil heavy metal pollution in other areas.

\section{Materials and methods}

\subsection{Case study}

\subsubsection{Study area and sampling}

Suzhou was located in the middle of the Yangtze river delta, the southeast of Jiangsu province, located at $119^{\circ} 55^{\prime} \mathrm{E}$ to $121^{\circ} 20^{\prime} \mathrm{E}, 30^{\circ} 47^{\prime \prime} \mathrm{N}$ to $32^{\circ} 02^{\prime} \mathrm{N}$, east of Shanghai, south of zhejiang, west of taihu lake, north of the Yangtze river, the total area of 8657.32 square kilometers. The city was low-lying and flat, with many rivers and lakes. Most of the water surface of taihu lake were in suzhou. Rivers, lakes and beaches accounted for $36.6 \%$ of the city's land area. Suzhou was a subtropical monsoon maritime climate, with an average temperature of $17.8^{\circ} \mathrm{C}$ and precipitation of 1369.2mm in 2018. The prevailing wind direction was southeast wind all year along, with four distinct seasons, mild climate, abundant rainfall, fertile land, rich natural conditions and so on. In the shallow layer, the clay soil with slight deformation and high strength was mainly grey, with compact texture.

\subsubsection{Sample collection and chemical analysis}

According to the land use pattern, topographic features and perennial wind direction in the study area, 30 composite topsoil samples in the $0-7 \mathrm{~cm}$ layer were randomly collected for measurement in Suzhou in October 2019 and the exact location of each point was recorded in Fig .1. The soil samples were taken back to the laboratory and naturally dried and ground crushing, first through a 20 mesh sieve for $\mathrm{pH}$ analysis, then used for the determination of physical 
and chemical properties (Pal et al., 2019). The processed soil samples were dissolved in the mixture acid solution

$117\left(\mathrm{HNO}_{3}-\mathrm{HF}-\mathrm{HClO}_{4}\right)$ at a high temperature of $210^{\circ} \mathrm{C}$ for $4 \mathrm{~h}$ (Bryanin et al., 2019). Soil $\mathrm{pH}$ was determined with a ratio 118 of 2:5 (w/v) soil/water mixture using a pH meter (Cheng et al. 2018). The soil organic matter (SOM) content was 119 determined by the chromic acid titration method. The content of heavy metals $\mathrm{As}, \mathrm{Cd}, \mathrm{Cr}, \mathrm{Zn}$ and $\mathrm{Pb}$ in soil samples were determined by by Inductively Coupled Plasma-Mass Spectrometry (ICP-MS, PerkinElmer ELAN 9000).

121 Atomic fluorescence photometer (AFS-230E) was used to analyze the content of Hg. Each batch of samples was 122 evaluated by reagent blanks to reduce errors for quality assurance (Jiang et al., 2019).

123 To ensure the quality of analysis, several quality assurance and control methods were conducted as the following standard operating procedures. Blank reagents, duplicate samples and soil standard reference samples (GBW0740107408, Beijing; National Center for Standard Materials of China) were operated in the Analytical and Testing Center of Suzhou research academy of North China Electric Power University. Chemical reagents are guaranteed reagents.

127 The logarithmic deviation of the system was within the range of \pm 0.045 (Zhang et al., 2017), and the relative percentage difference between duplicate samples was within the range of $\pm 7.50 \%$ (Han et al., 2006). Therefore, the precision and bias of the analysis were generally below $5 \%$. 


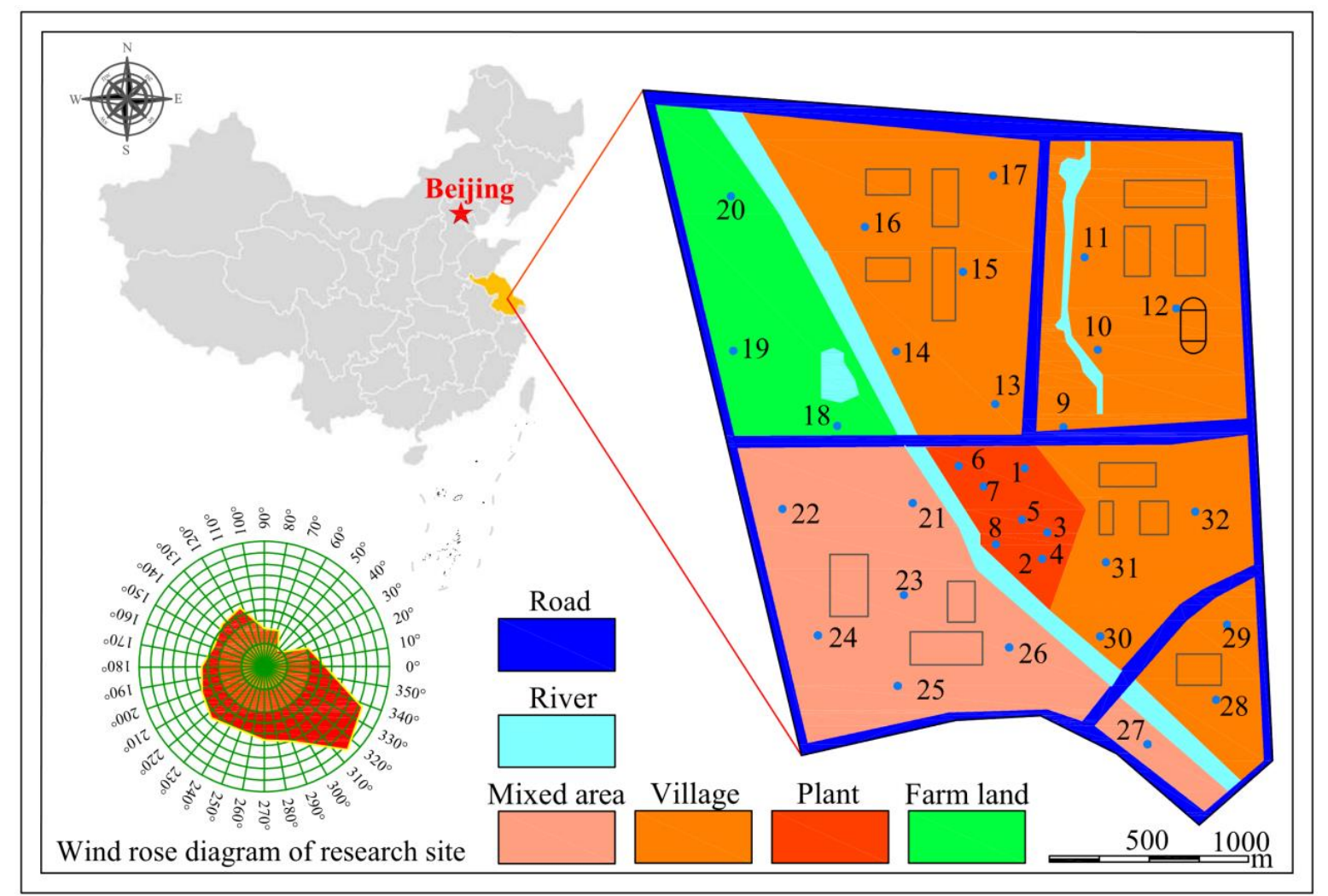

Fig. 1. Sampling sites of soil heavy metals in the study area.

\subsubsection{Statistical analysis}

Microsoft Excel (version 2010, USA) was used for calculations. The spatial distribution of soil heavy metals was mapped by the Surfer v.12.0 (Golden Software Inc., CO, USA) and ArcGIS 10.7 software. SPSS Statistics 25 (IBM Inc., CO,USA) was used to conduct the analyses and to obtain the relevant parameters. The data underwent by EPAPMF 5.0 to assess the sources of soil heavy metals with a $95 \%$ confidence interval (significance $p<0.05$ ). Crystal Ball Software (Version 2000, Decisioning, Denver, CO, USA) was employed for uncertainty analysis.

\subsection{Overview of the framework}

The city of Suzhou studied in this paper has a thriving ecotourism industry and there are abandoned industrial polluted sites that have not been treated. Therefore, it is necessary to pay attention to the environmental health risks in this region. The objective of this study is to conduct a combination of source analysis and health risk assessment methodology to characterize the soil heavy metal pollution levels of the sources and source-specific human health risk. The integrated framework of the method combined source apportionment and source-specific human health risk 
Firstly, the pollution sources is determined qualitatively by PCA analysis, and then the PMF source apportionment

is carried out according to the obtained results to accurately define the types of sources and the distribution rate of

pollution sources, which complement each other. Secondly, the spatial distribution of heavy metals in contaminated sites were studied by spatial interpolation based on the comparison of Ordinary kriging and inverse distance weighted. incorporated into the health risk assessment model to identify heavy metal from identified sources. Thirdly, toxic metal with a large contribution from pollution sources and high risk level was screened out and the correlation and total effects of health risks have also been analyzed. Finally, we identify which sources of contamination need attention and which toxic metals need to be prioritized for removal or reduction of toxic emissions. Based on the above information, targeted risk reduction strategies can be developed. It provided a theoretical basis for the government to control heavy metal pollution scientifically (Huang et al., 2006; Luo et al., 2011).

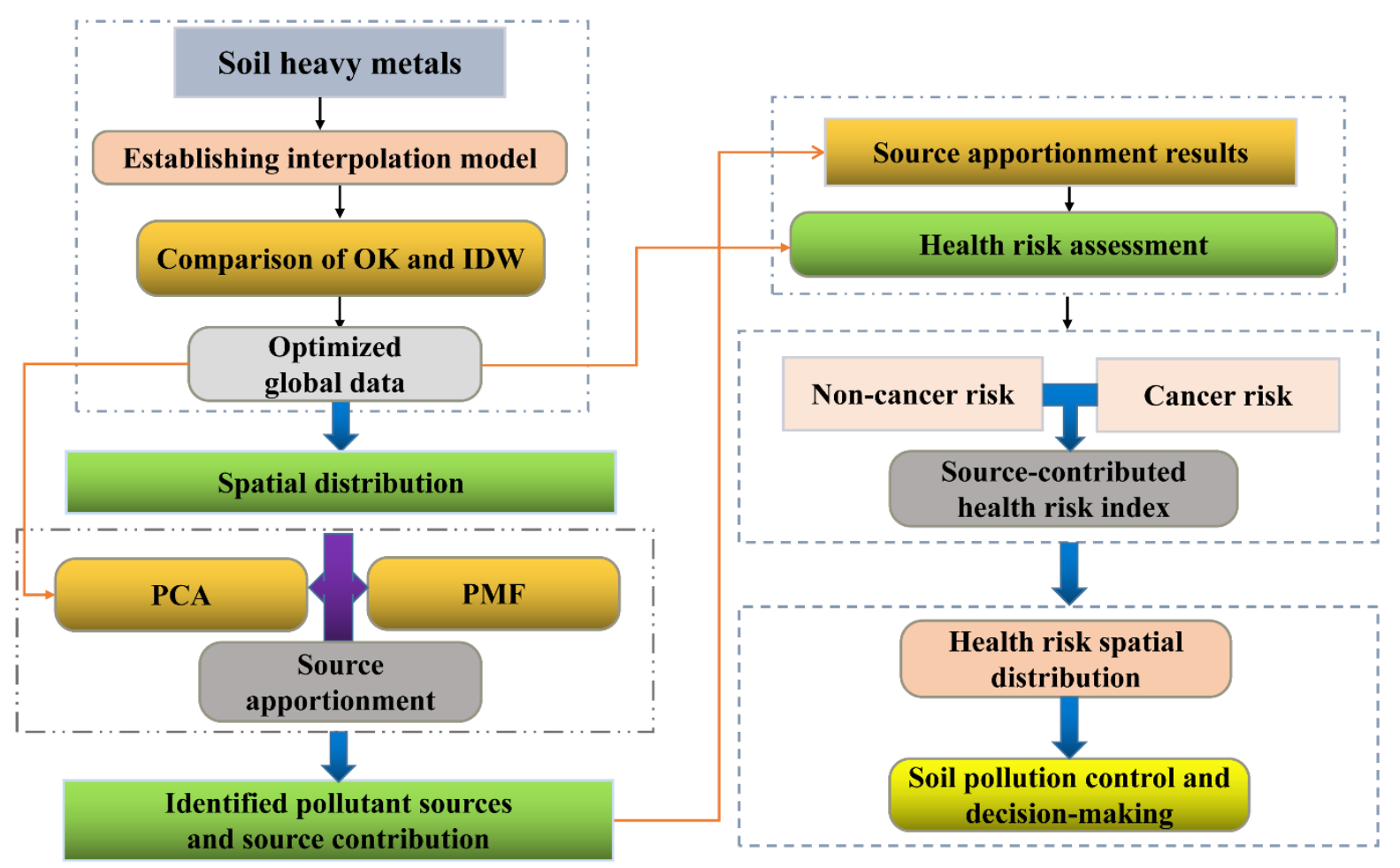

Fig. 2. Frameworks of the methodology for soil heavy metals.

\subsection{Optimization of spatial interpolation for global data of heavy metals}


Ordinary kriging was a type of kriging interpolation, which assumed that the property values were spatially the attributes of unknown points, which was mainly used to interpolate the parameters of un-sampled locations. The concentrations of soil heavy metals of the unknown point (x) was defined in Eq. (1).

$$
C_{(x)}^{t}=\sum_{i=1}^{n} \lambda_{i} C_{\left(x_{i}\right)}^{t}
$$

where, the $C_{(x)}^{t}$ was predicted concentration of soil heavy metals $t(t=(\mathrm{As}, \mathrm{Cd}, \mathrm{Cr}, \mathrm{Hg}, \mathrm{Pb}$ and $\mathrm{Zn})$ at unknown site of $\boldsymbol{x} ; \boldsymbol{C}_{\left(x_{i}\right)}^{t}$ was the content of metal $t$ at point $x_{i}(i=1,2 \ldots, \mathrm{i}, \ldots \mathrm{j}, \ldots n)$; was the concentration at the sampling point $\boldsymbol{x}_{i}$;

$\lambda_{i}$ was the weight coefficient, which would be calculated by Eq. (2).

$$
\left\{\begin{array}{l}
\sum_{i=1}^{n} \sum_{j=1}^{n} \lambda_{j} \gamma\left(x_{i}, x_{j}\right)+\mu=\gamma\left(x_{i}, x\right) \\
\sum_{i=1}^{n} \lambda_{i}=1
\end{array}\right.
$$

where, the $\boldsymbol{x}_{\boldsymbol{j}}$ was another known point; $\boldsymbol{\mu}$ was the lagrangian constant; $\boldsymbol{\gamma}\left(\boldsymbol{x}_{i}, \boldsymbol{x}_{\boldsymbol{j}}\right)$ was the semi-variogram function and could be obtained by Eq. (3).

$$
\left.\gamma(h)=1 / 2 E\left[C_{(x)}^{k}\right)^{k}(x+h)\right]^{2}
$$

169 Where, $E$ was the number of sample pairs at a separation vector $h$.

\section{Step 2: Inverse distance weighted (IDW)}

The IDW method has a wide range of applications in the field of geology, which can be simplified as the estimation

process of calculating the spatial variables of the concentration of heavy metals at unmeasured locations by observing a large number of measured samples in the space close to the target location. 
$C_{x}^{k}=\sum_{i=1}^{n} \frac{C_{i}^{k}}{D_{i}} / \sum_{i=1}^{n} \frac{1}{D_{i}}$

178 Where, $D_{i}(i=1,2 \ldots, n)$ was the horizontal distance between interpolation point and reference point.

\section{Step 3: Verification method}

The accuracy of spatial interpolation methodology was verified by cross-validation model. The accuracy of both

Ok and IDW interpolation methods was evaluated by examination of the errors of observed value $(\mathrm{OV})$ and the predicted value $(P V)$. The slope and determination coefficient $\left(R^{2}\right)$ of fitting line between the $P V$ and the $O V$ approaching to 1 indicated that the method would be more accurate.

\subsection{Mathematical models for source apportionment}

The PCA model was utilised to identify the sources of soil heavy metal pollution qualitatively first, and then the PMF model was adopted for quantitative analysis to characterise the contribution of each source to soil heavy metal pollution. A combined analysis was eventually undertaken based on the types of pollution sources obtained from the two to accurately obtain the pollution sources and source contribution rates. The PCA/PMF model in combinatorial form can effectively validate the two with each other to obtain a thorough and comprehensive assessment.

\subsubsection{Principal component analysis}

Principal Component Analysis (PCA) was a statistical method that simplified the data structure primarily by dimensionality reduction, converting multiple variables into a small number of variables. PCA model could remodel the initial data into a collection of linearly freelance representations of every dimension through linear transformation, which can be used to extract the main feature components of data and was usually used for spatiality reduction of high-dimensional data. The application of PCA in environmental science has been relatively mature, which can effectively analyze the potential pollution sources and spatial distribution of heavy metals in soil (Xiao-Bo et al., 2009). PCA was often used to identificate the natural and anthropogenic sources of heavy metals by means of using chemical element principal factor loading (Cai et al., 2018; Hani and Pazira, 2011; Li et al., 2015).

\subsubsection{Positive matrix factorization}


The positive matrix factorization (PMF) method was one of the source analytical methods recommended by the

U.S. Environmental Protection Agency (Paatero et al., 2010). PMF was a factor analysis method based on the least square method, which decomposed the matrix without negative constraints and can be optimized by means of standard deviation of data (Chen et al., 2011). It did not rely on the chemical composition spectrum analysis of pollution sources, but took the data sets of multiple soil samples and heavy metal elements as a matrix, and then decomposed the matrix into the contribution rate matrix and the source composition spectrum matrix (Dong et al., 2018; Franco et al., 2009). Through non negative constraint factor analysis and iterative calculation with the least square method, the objective function was minimized to solve chemical mass balance between the measured heavy metal concentration and pollution source (Guan et al., 2018). Compared with the traditional factor analysis method (such as FA-MLR), the PMF method could avoid the negative value in the result of matrix decomposition, so that the obtained source component spectrum and source contribution rate can be explained and had clear physical significance (Lv et al., 2019). In addition, the PMF used error estimates for each individual data point in order to cope with missing and inaccurate data more reasonably (Mamut et al., 2017). The data entered into the program include concentrations and equation-based uncertainties (Jing et al., 2014).

The PMF had a unique advantage because it could be used without source components as input. It was also applied

to environmental data processing because it contained variable uncertainties associated with environmental sample measurements and forced all values to be non-negative (Xue et al., 2014). Compared with the traditional source apportionment methods, PMF was used to analyze pollution sources of heavy metals by weighing all data to analyze the contribution rate of target variables (Tian et al., 2018). The method based on matrix equation was as follows:

$$
\begin{aligned}
& C_{i k}=\sum_{l}^{p} g_{i p} f_{p k}+e_{i k} \\
& Q=\sum_{1}^{i} \sum_{1}^{k}\left(e_{i k} / u_{i k}\right)^{2}
\end{aligned}
$$

Where, the $C_{i k}$ was the concentration of the $k_{\mathrm{th}}$ for soil heavy metals at the $i_{\text {th }}$ sample; $g_{i p}$ was the contribution of 
deviation of the $k_{\text {th }}$ for soil heavy metals at the $i_{\text {th }}$ sample; $Q$ was the objective function; $u_{i k}$ was the uncertainty of the

$222 k_{\text {th }}$ for soil heavy metals at the $i_{\text {th }}$ sample.

223 The contribution rate of source $m$ was obtained by Eq. (7).

$g \%=\left(A_{m} / \sum_{m=1}^{p} A_{m}\right) \times 100 \%$

224 Where, the $\boldsymbol{A}_{\boldsymbol{m}}$ referred to the regression coefficient for $p_{t h}$ source (Liu et al.,2018; Larsen and Baker, 2003).

\subsection{Health risk assessment based on source-oriented model}

Exposure to heavy metals may cause potential adverse effects on human health due to heavy metal toxicity.

Therefore, certain risk assessment model was developed by the USPEA and used frequently for the risk assessment.

There were three exposure routes contributed to the average daily dose $(\boldsymbol{A D D})$ via ingestion, inhalation and dermal

$$
\begin{aligned}
& A D D_{\text {ing }}=C \times \operatorname{IngR} \times E F \times E D /(B W \times A T) \times 10^{-6} \\
& A D D_{\text {inh }}=C \times I n h R \times E F \times E D /(P E F \times B W \times A T) \\
& A D D_{\text {dermal }}=C \times S L \times S A \times A B S \times E F \times E D /(B W \times A T) \times 10^{-6} \\
& H I=\sum_{i=1}^{3} H Q=\sum_{i=1}^{3} A D D_{i} / R f D_{i} \\
& T H I=\sum H I \\
& C R_{s c}^{t i}=A D D_{i} \times S F_{i}
\end{aligned}
$$

$231 \boldsymbol{i}$ represented each different exposure pathways of heavy metal entering the human body. $\boldsymbol{R} \boldsymbol{f D}$ was the reference dose (mg/kgd) and parameters of detailed description of $\boldsymbol{R} \boldsymbol{f D}$ were shown in Table S1; The hazard index $(\boldsymbol{H I})$ is the sum of HQs (Eq. (12)). The total hazard index (THI) is the sum of $\boldsymbol{H I}\left(\mathbf{E q}\right.$. (13)). $\boldsymbol{C R}_{s c}{ }^{t i}$ represented the carcinogenic risk index of evaluating carcinogenic hazards of heavy metals (Zhang et al., 2018b). The other parameters were provided by supplementary material in Table $\mathbf{S 2}$.

To better clarify the impact of pollution sources of heavy metals on human health, quantitative source 


$$
\begin{aligned}
& H I^{k}=H Q_{i n g}^{k}+H Q_{i n h}^{k}+H Q_{d e r}^{k} \\
& H I_{s c}^{k, p}=H I^{k} \times g_{p}^{k} \\
& T H I_{s c}^{k, p}=\sum_{I}^{k} H I_{s c}^{k, p}
\end{aligned}
$$

239 Where $H I_{s c}^{k, p}$ was the source contributed hazard index of the $k_{\text {th }}$ for soil heavy metals in the $p_{\text {th }}$ source; $T H I_{s c}^{k, p}$ was the total source contributed hazard index of soil heavy metals in the $p_{\text {th }}$ source.

241 Carcinogenic risk $(\boldsymbol{C R})$ for adults and children was evaluated to assess carcinogenic health effects on humans.

242 When $\boldsymbol{C} \boldsymbol{R}$ and $\boldsymbol{T C R}$ greater than $1 \times 10^{-4}$ were considered as unacceptable, while $\boldsymbol{C R}$ and $\boldsymbol{T C R}$ lower than $1 \times 10^{-6}$ was 243 considered as no significant carcinogenic effects on humans.

$$
\begin{aligned}
& T C R^{k}=C R_{i n g}^{k}+C R_{i n h}^{k}+C R_{d e r}^{k} \\
& C R_{s c}^{k, p}=C R^{k} \times g_{p}^{k} \\
& T C R_{s c}^{k, p}=\sum_{1}^{k} C R_{s c}^{k, p}
\end{aligned}
$$

244 Where $C R_{s c}^{k, p}$ was the source contributed carcinogenic risk of the $k_{\text {th }}$ for soil heavy metals in the $p_{\text {th }}$ source; $T C R_{s c}^{k, p}$ 245 was the total source contributed carcinogenic risk of all soil heavy metals in the $p_{\text {th }}$ source.

246 Combined with quantitative source apportionment and risk assessment, the source-contributed health risk was 247 calculated. Human health risks of the pollution sources corresponding to soil heavy metals would be clearly displayed, 248 which was mainly to assess the hazards to human health of each specific source of pollution. The source-contributed 249 health risk was calculated by Eq. (21) to (22).

$$
\begin{aligned}
& S C H I=H I_{s c}^{k, p} g \% \\
& S C C R=C R_{s c}^{k, p} g \%
\end{aligned}
$$

Where, the $\boldsymbol{S C H I}$ and $\boldsymbol{S C C R}$ represented the source-contributed non-carcinogenic and carcinogenic risk index of each sources, respectively. 


\subsection{Description and optimized spatial interpolation of soil heavy metals}

The $\mathrm{pH}$ value of the soil detected from the site studied was ranged from 7.03 to 7.57 , the average value of which

was 7.24. The summary statistics of heavy metals in soil from the site were presented in Table 1 . The mean concentrations of different heavy metals decreased following the order: $\mathrm{Cr}>\mathrm{Zn}>\mathrm{Pb}>\mathrm{As}>\mathrm{Cd}>\mathrm{Hg}$. Compared with the background value, the mean concentrations of $\mathrm{Cd}, \mathrm{Hg}$ and $\mathrm{As}$ were relatively higher than the background values $(\boldsymbol{B} \boldsymbol{V})$, accounting for percentages of $415.9 \%, 239.6 \%$ and $77.05 \%$ above $\boldsymbol{B} \boldsymbol{V}$, respectively. Additionally, the highest coefficient of variation $(\boldsymbol{C V})$ of heavy metal turned out to be $\mathrm{Hg}$ followed by As and $\mathrm{Zn}$, which indicated that the extensive variation may be affected by multiple factors, especially the anthropogenic activities (Fu et al., 2014). them were lower than $50 \%$, indicating moderate variability in the study area.

Table 1

264 Summary statistics for heavy metal concentrations $\left(\mathrm{mg} \mathrm{kg}^{-1}\right)$ in soils.

\begin{tabular}{ccccccc}
\hline Element & Pb & Hg & Cr & Cd & As & Zn \\
\hline Min & 5.46 & 0.02 & 7.10 & 0.81 & 2.08 & 6.95 \\
Max & 81.57 & 1.51 & 80.59 & 28.95 & 56.88 & 84.32 \\
Mean & 28.42 & 0.18 & 71.03 & 0.65 & 17.75 & 69.45 \\
Median & 24.71 & 0.13 & 71.12 & 0.56 & 14.40 & 70.43 \\
Variance & 145.04 & 0.033 & 0.073 & 16.51 & 124.33 & 78.97 \\
SD & 12.04 & 0.18 & 0.27 & 4.06 & 11.15 & 65.63 \\
CV & 0.32 & 1 & 0.26 & 0.39 & 0.63 & 0.49 \\
BV & 26.20 & 0.053 & 77.80 & 0.126 & 10.0 & 62.60 \\
AV & 27.0 & 0.071 & 61.0 & 0.097 & 11.0 & 74.00 \\
Chinese soil criteria $^{\mathrm{c}}$ & 250 & 2.5 & 150 & 0.3 & 30 & 200 \\
Percent & $8.50 \%$ & $239.6 \%$ & 0 & $415.9 \%$ & $77.05 \%$ & $10.94 \%$ \\
\hline
\end{tabular}

Note: GM- geometric mean; SD- standard deviation; CV- coefficient of variation; Percent- percentage above BV;

a BV-Background value of Jiangsu (Ma et al., 2015);

${ }^{\mathrm{b}}$ AV-Average value of China (Wang et al. 2019a);

$268{ }^{\mathrm{c}}$ Chinese soil criteria (CNEPA (1995)).

Trend analysis was performed according to the correlation coefficient between observed values $(\boldsymbol{O} \boldsymbol{V})$ and predicted 
$\boldsymbol{R}^{2}$ can fit the correlation between the simulated concentration and the observed concentration of soil heavy metals in

273 the spatial interpolation models (Islam et al., 2018). The results shown in Fig. 3 indicated that it was more reliable to

274 estimate the spatial distribution for the geological data colledted. The Results demonstrated that the $\boldsymbol{P} \boldsymbol{V}$ and $\boldsymbol{O} \boldsymbol{V}$ values

275 were more close in the linear fit of heavy metals extracted by the $\boldsymbol{O} \boldsymbol{K}$ method. Therefore, $\boldsymbol{O} \boldsymbol{K}$ can provide a more accurate prediction of the spatial distribution characteristics of heavy metals than IDW. $O K$ allowed for the spatial correlation of regional variables and the introduced variance function expressions to obtain globally optimal interpolation data (Shahbeik et al., 2014). The introduced variance function can reduce the error in the spatial interpolation results of heavy metals. Therefore, $\boldsymbol{O K}$ was more appropriate for the spatial distribution of the heavy metals characterised in this study.
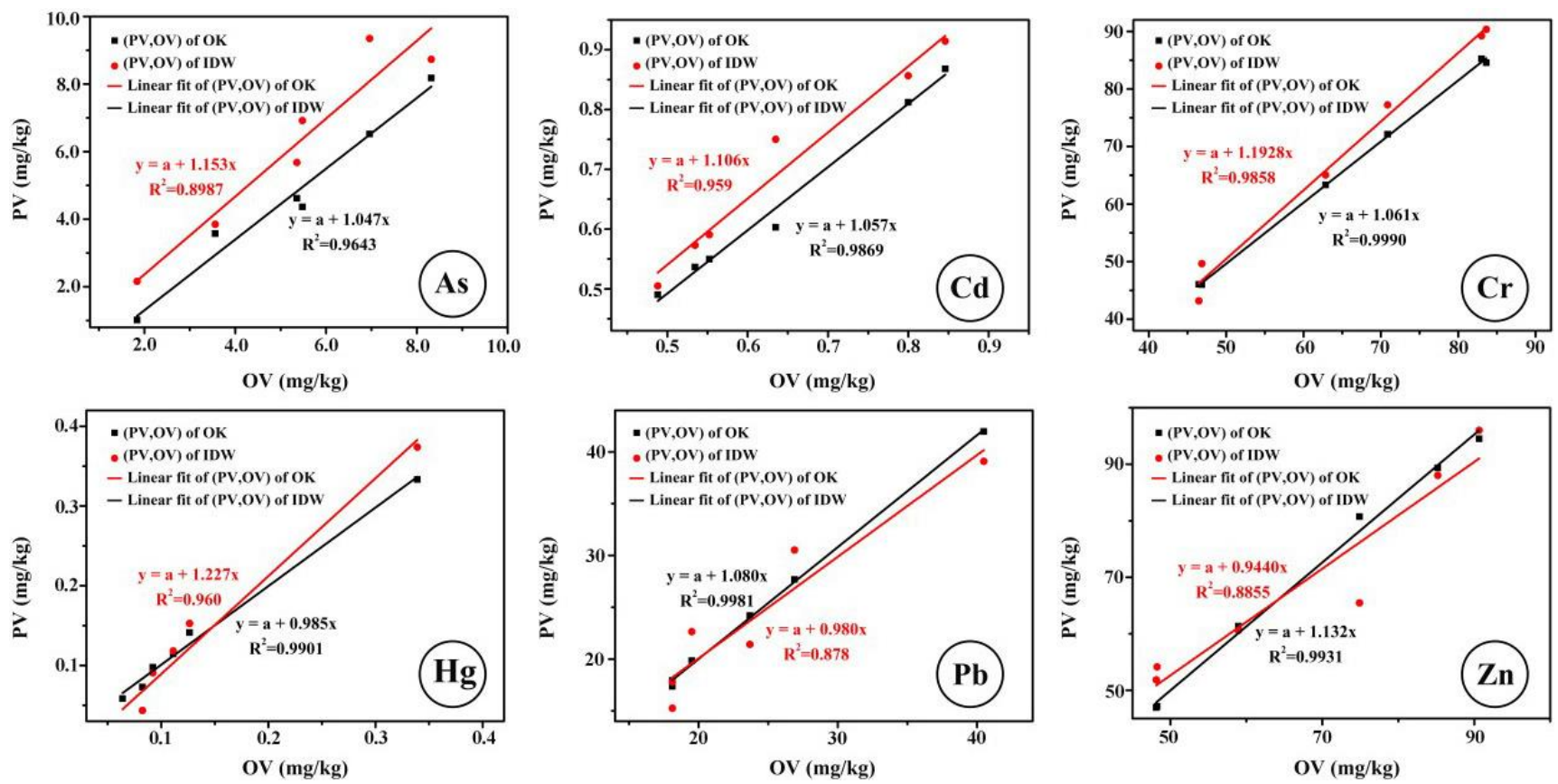

Fig. 3. Liner fitting for the predicted and observed values of soil heavy metals by $O K$ and $I D W$.

Hence, the spatial distribution of the concentrations of heavy metals in the study area was depicted by means of

$\boldsymbol{O K}$ interpolation technique. As it can be seen from Fig. 4, the highly concentrated areas of spatial distribution of Cd

were mainly in the north and south-west of the study area. The concentrations of $\mathrm{Pb}$ and $\mathrm{Zn}$ had a similar tendency 

overuse of fertilisers may lead to the accumulation of As.

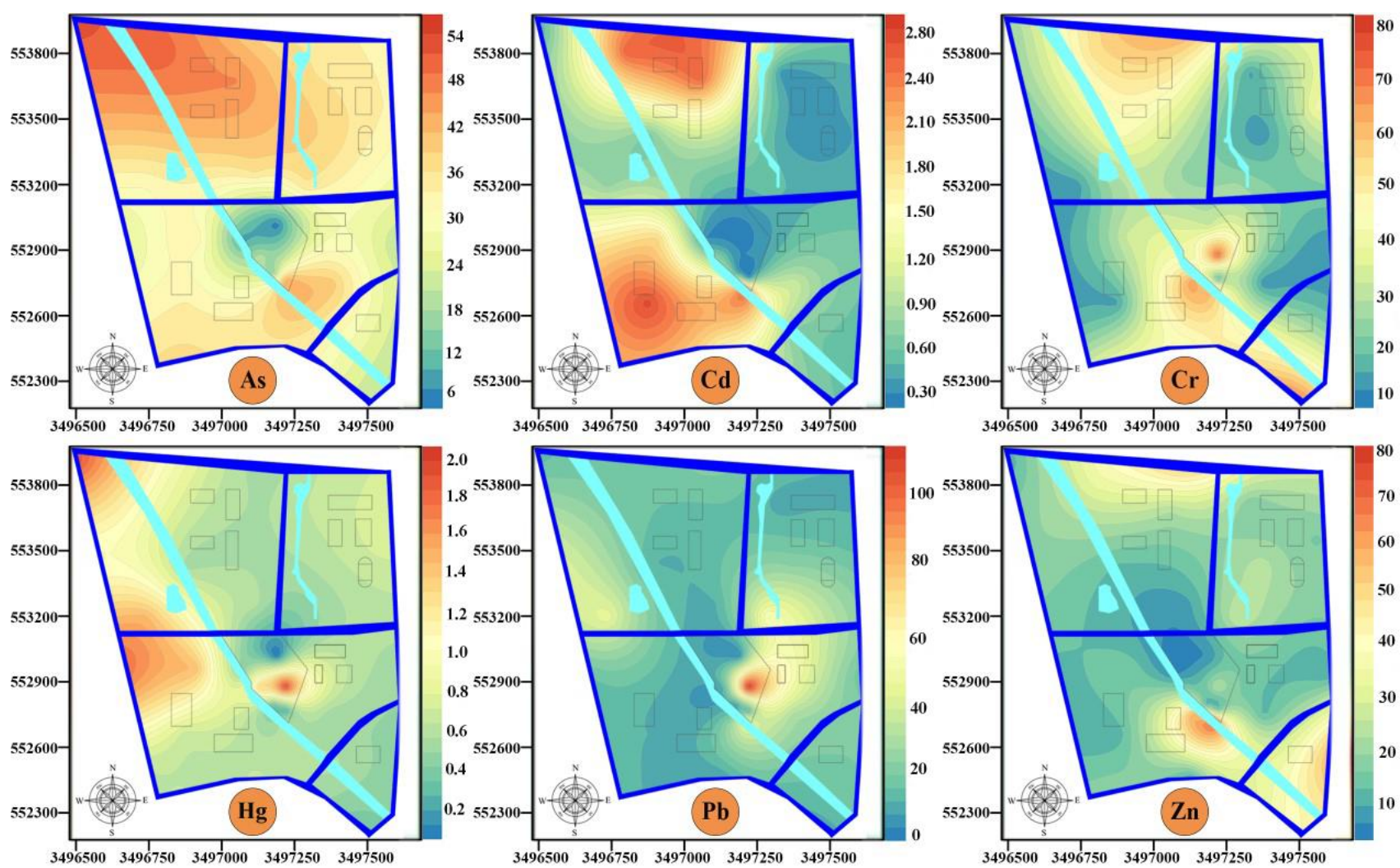

Fig. 4. Spatial distributions of soil heavy metals in the study area using the interpolation model of $\boldsymbol{O K}$.

\subsection{Quantitative source apportionment in the study area}

\subsubsection{Pollution sources identification}

The factor loading results by PCA for concentrations of soil heavy metals were showed in Fig. 5a. As shown in factors of heavy metals elements to the total variance was the main factor in the determination of major pollutants. 
The first PC (PC1) in component matrix demonstates that the contaminationof $\mathrm{Cr}$ originated in the same sources

perhaps, such as waste-water, industrial contamination, lithogenic processes and solid waste. The second PC (PC2)

which consists of $\mathrm{Zn}$ and $\mathrm{Pb}$ can be defined as anthropogenic components, such as vehicle, industrial fumes which was a common source of lead contaminationin soil (Facchinelli et al., 2001). The high Cd level in the third PC (PC3) may be related to traffic activities and diesel exhaust. The high scores of PC4 mainly including As and Hg maybe related to the combination of industrial and agricultural activities (Luo et al., 2017). The rotation ofthe matrix displayed the same relationship between these heavy metals, which is useful to explain ambiguities in the component matrix.

\subsection{2. pollution sources contribution}

PMF model was implemented to obtain relevant data to better identify the sources and contributions of heavy metals in soil (Wang et al., 2019). Five factors were loaded and the percentage of the total number of species was presented in Fig. 5b. Factor 1 accounted for a high percentage of $\mathrm{Hg}(56.6 \%)$ and $\mathrm{Cr}$ (32.7\%), the high $\boldsymbol{C V}$ of which reflecting that they may be related to anthropogenic sources (Guan et al., 2018). Such as Hg emissions brought about by human activities and the emissions caused by waste treatment. On the other hand, $\mathrm{Cr}$ can be attributed to emissions of vehicle activities from the traffic roads (Parra etal., 2014). Factor 2 was dominated by $\mathrm{Pb}$ and $\mathrm{Zn}$, with a percentage of $44.8 \%$ and $55.6 \%$, respectively. It was noted that the concentrations of $\mathrm{Pb}$ and $\mathrm{Zn}$ were close to the background values. High concentration distributions of $\mathrm{Pb}$ and $\mathrm{Zn}$ were mainly concentrated nearby the traffic road, which can be inferred that the contaminants were from traffic activities or fossil fuel. Factor 3 explained $40.97 \%$ of the total species to As, which may be caused by utilization of agrochemicals (Xiao et al., 2019). Thus because As was the main element in the use of pesticides to farmland (Cai etal., 2015). The sharp concentration area of As was around the sampling site S18 nearby the farmland on the map (Salim et al., 2019). Previous studies had also confirmed that the enrichment of arsenic was due to the use of pesticides (Liang et al., 2017b). Factor 4 was defined mainly by $\mathrm{Cr}$ accounting for $45.7 \%$ and the accumulation of $\mathrm{Cr}$ was mainly associated fine particles from the road area, including 
atmospheric deposition, coal burning, printing and dyeing industry and metal processing (Wu et al., 2015). Cd accounted for a large proportion in factor 5 with the percentage of $44.0 \%$, the main sources of Cd pollution were lead-zinc mines, smelting of non-ferrous metals, electroplating and factories that use cadmium compounds as raw

327 materials or catalysts, the same polluted sources as the factor 4 (Wang et al., 2019). The high $\boldsymbol{C V}$ value and higher mean concentration compared with the background value, showing the influence of artificial factor (Gao et al., 2018;

329 Peng et al., 2017). According to the foregoing investigation, the textile and dyeing industries attributed high content of Cd from the emission of the sewage of dyeing activities (Wang et al., 2019; Luo et al., 2011; Sun et al., 2019). The high concentration area and high risk area of metal $\mathrm{Cd}$ were all around the dye factory as investigated. Therefore it was concluded that there were four sources of pollution dominating the contaminated site. Comparatively speaking,

333 industrial activities occupied the largest contribution to soil heavy metals in the study area; followed by the human 334 activities such as waste emission. The third largest contribution was made by agricultural activities, which were 335 related to the farmland in the study area. Owing to the frequent utilization of vehicle and fuel near the roads, traffic activities accounted for the fourth largest contribution and the followed one was atmospheric deposition. The results were consistent with the current situation of the whole study area, with abandoned factories, developed transportation around and frequent agricultural activities, indicating the close relationship between the dye factory and its surrounding soil.

Therefore, the number of factors ought to be set to four within the PMF run by the results of PCA, at that purpose the simplest analysis results were achieved with a run variety of fifty. Additionally, the coefficients of the six heavy metal components shown in Table $\mathbf{S 3}$ varied between $0.35 \sim 0.99$, indicating that the overall fit of the PMF was sensible. 
a

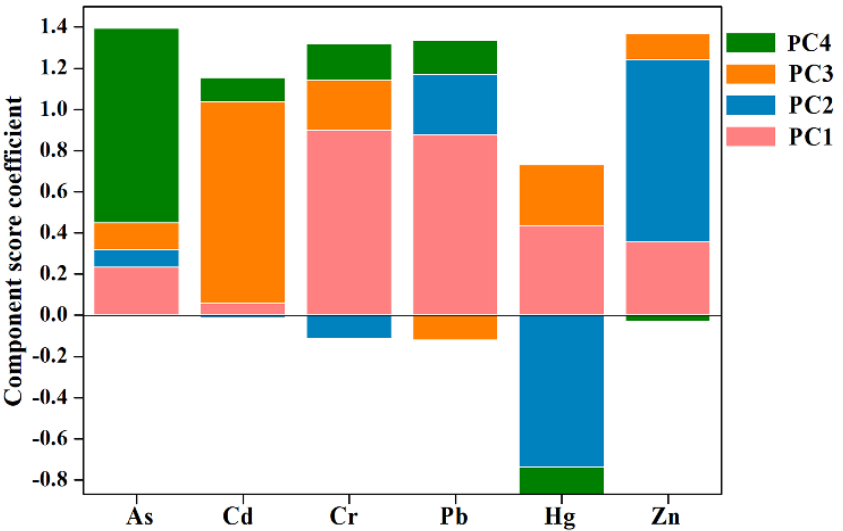

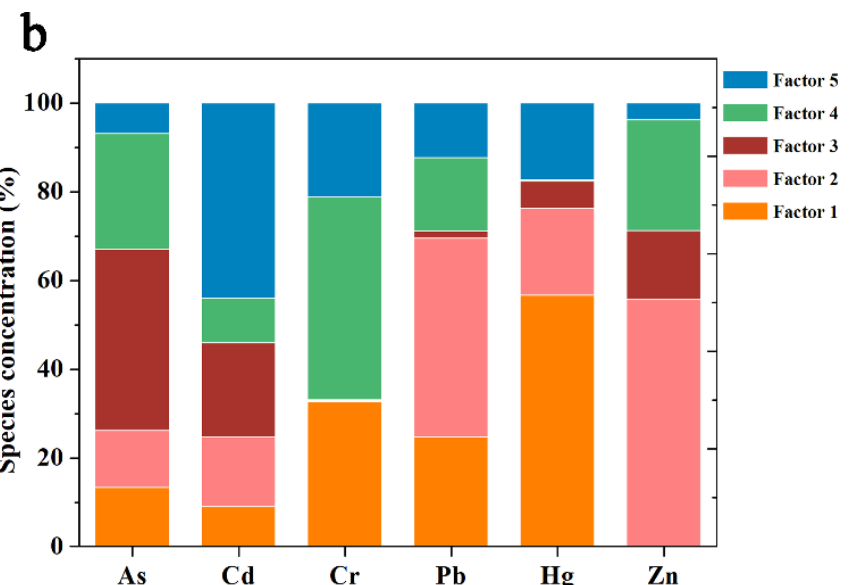

Fig. 5. (a) Component source coefficient by PCA analysis and (b) source contributions for each heavy metal estimated by PMF model.

\subsection{Human risk assessment}

\subsubsection{Human risk assessment of heavy metals}

The upper limit of $95 \%$ confidence intervals of regional survey data $\left(\mathrm{C}_{95 \%} \mathrm{UCL}\right.$ in $\left.\mathrm{mg} / \mathrm{kg}\right)$ was considered to evaluate of the maximum intake daily dose for human health risk assessment (USEPA, 1989). The original data of $\boldsymbol{H Q}, \boldsymbol{H I}$ and $\boldsymbol{T H I}$ (adults and children) by means of classical health risk assessment were presented in Table 2 . The highest average intake turned out to be the ingestion pathway and the order followed were: dermal contact $>$ inhalation. In the ingestion pathway, average $\boldsymbol{H Q}$ ranged as: $\mathrm{As}>\mathrm{Cd}>\mathrm{Pb}>\mathrm{Hg}>\mathrm{Cr}>\mathrm{Zn}$. $\boldsymbol{H Q}$ s for six heavy metals were less than 1 both for adults and children, indicating that there were no significant health risks. However, the $\boldsymbol{T H I}$ value of children through ingestion pathway was 1.00 , posing potential health threat to the children. The contribution of As to non-carcinogenic risk was $76.9 \%$, which should be paid attention to in this region. The $\boldsymbol{C R}$ values of $\mathrm{As}, \mathrm{Cd}, \mathrm{Cr}, \mathrm{Hg}$, $\mathrm{Zn}$ and $\mathrm{Pb}$ were evaluated by health risk assessment and the results showed that $\boldsymbol{C R}$ index of the whole region for the six heavy metals were all less than 1.0E-06 through ingestion of exposure, indicating that there was no carcinogenic risk in this region. Therefore, the source-contributed assessment of health risks mainly focused on the evaluation of non-carcinogenic health risk. Then the modified assessment of human health risk for five heavy metals was performed based on source contribution (Li etal., 2020). 
Estimations of human health risk of soil heavy metals.

\begin{tabular}{|c|c|c|c|c|c|c|c|c|c|}
\hline & Element & $\mathbf{P b}$ & Hg & $\mathrm{Cr}$ & Cd & As & $\mathbf{Z n}$ & HI & THI \\
\hline & $C-95 \%$ & 28.75 & 0.19 & 71.02 & 0.76 & 18.05 & 68.50 & & \\
\hline \multirow{4}{*}{ Adults } & $H Q_{\text {ing }}$ & $1.13 \mathrm{E}-02$ & 8.68E-04 & 4.70E-04 & $1.20 \mathrm{E}-02$ & $8.24 \mathrm{E}-02$ & $3.13 \mathrm{E}-04$ & $1.07 \mathrm{E}-01$ & \multirow{3}{*}{$1.08 \mathrm{E}-01$} \\
\hline & $H Q_{\text {der }}$ & $4.46 \mathrm{E}-05$ & $3.44 \mathrm{E}-06$ & $1.97 \mathrm{E}-04$ & 4.79E-05 & $3.28 \mathrm{E}-04$ & $1.25 \mathrm{E}-05$ & $6.33 \mathrm{E}-04$ & \\
\hline & $H Q_{\text {inh }}$ & $1.10 \mathrm{E}-05$ & $6.38 \mathrm{E}-07$ & $3.46 \mathrm{E}-06$ & $1.76 \mathrm{E}-04$ & $2.96 \mathrm{E}-05$ & $2.30 \mathrm{E}-07$ & $2.21 \mathrm{E}-04$ & \\
\hline & $H Q_{\text {ing }}$ & $1.05 \mathrm{E}-01$ & $8.10 \mathrm{E}-03$ & 4.39E-03 & $1.12 \mathrm{E}-01$ & 7.69E-01 & 2.92E-03 & $1.00 \mathrm{E}+00$ & \multirow{3}{*}{$1.00 \mathrm{E}+00$} \\
\hline \multirow[t]{2}{*}{ Children } & $H Q_{\mathrm{der}}$ & $2.92 \mathrm{E}-05$ & $2.25 \mathrm{E}-06$ & $1.29 \mathrm{E}-04$ & $3.14 \mathrm{E}-05$ & $2.15 \mathrm{E}-04$ & $8.16 \mathrm{E}-06$ & $4.15 \mathrm{E}-04$ & \\
\hline & $H Q_{\text {inh }}$ & $1.96 \mathrm{E}-05$ & $1.14 \mathrm{E}-06$ & $6.16 \mathrm{E}-06$ & 3.14E-04 & $5.26 \mathrm{E}-05$ & 4.10E-07 & 3.94E-04 & \\
\hline
\end{tabular}

\subsubsection{Source-contributed health risk assessment}

The source contribution of $\boldsymbol{S C C R}$ and $\boldsymbol{S C H I}$ was calculated to evaluate the risk level of the source. The results of

source analysis were incorporated into the health risk model to assess the potential hazards to human health by soil

heavy metals. The calculation of source-contributed health risk assessment could demonstrate the relationship

between pollutants sources and health risk, as shown in table. 3. The contributions of the carcinogenic risk assessment

for the heavy metals were demonstrated in Fig. 6a. Cr originated from anthropogenic sources, of which $\mathrm{Cr}$ accounted

for 5.79E-04. For As, with a high $\boldsymbol{S C C R}$ index of 4.50E-04, accounted for the major contributor in the agricultural activities. For $\mathrm{Cr}$, industrial sources was the main source of pollution in the high $\boldsymbol{S C C R}$ area with a $\boldsymbol{S C C R}$ index of 1.09E-03. The carcinogenic risk allocation was consistent for adults and children, but the risk values of adults were lower than that for children. The TCRs of the sources were in the order of industry (6.42E-04), agriculture (4.59E04), transportation (4.11E-04), and atmosphere (3.23E-04). The industrial sources had the highest $\boldsymbol{T C R}$, indicating harmful effects from the activities of the dye plant. There was a potential carcinogenic hazard in the study area, for which reasonable programmes should be developed to reduce or isolate the input or transport of industrial and agricultural sources. In addition, some activities, particularly industrial and agricultural activities, should be controlled to reduce population health and environmental risks.

$\mathrm{Hg}$ and $\mathrm{Cr}$, industrial sources were the main contributors to $\boldsymbol{S C H I}$, accounting for 3.36E-01 and 3.97E-01, 
respectively. For $\mathrm{Pb}$ and $\mathrm{Zn}$, traffic activities was the largest contributor to $\boldsymbol{S C H I}$, accounting for 7.94E-02 and 2.45E-

02, respectively. For As, the higher $\boldsymbol{S C H I}$ came from agricultural activities, with the risk values of 7.96E-02. For Cd,

$\boldsymbol{S C H I}$ was higher from industrial sources at 6.80E-02. The largest contributor to $\boldsymbol{T H I}$ was industry (6.85E-01),

THI and were mainly associated with emissions caused by waste treatment of the dye factory, which may contribute

Estimation of non-cancer (hazard index) and cancer risk (total cancer risk) of heavy metals from four sources.

\begin{tabular}{|c|c|c|c|c|c|c|c|c|c|c|}
\hline & \multicolumn{5}{|c|}{ Children (aged 1-17) } & \multicolumn{5}{|c|}{ Adults（aged 18+） } \\
\hline & Factor 1 & Factor 2 & Factor 3 & Factor 4 & Total factors & Factor 1 & Factor 2 & Factor 3 & Factor 4 & Total factors \\
\hline & \multicolumn{4}{|c|}{ hazard index and total hazard index } & \multicolumn{6}{|c|}{ hazard index and total hazard index } \\
\hline As & $1.40 \mathrm{E}-01$ & $1.00 \mathrm{E}-02$ & $7.96 \mathrm{E}-02$ & $5.04 \mathrm{E}-02$ & $4.00 \mathrm{E}-01$ & $1.51 \mathrm{E}-03$ & $1.08 \mathrm{E}-03$ & $9.64 \mathrm{E}-03$ & 7.-7E-03 & 4.30E-02 \\
\hline $\mathrm{Cd}$ & $1.35 \mathrm{E}-03$ & $9.65 \mathrm{E}-04$ & $8.65 \mathrm{E}-04$ & $6.80 \mathrm{E}-02$ & $3.86 \mathrm{E}-03$ & $1.47 \mathrm{E}-04$ & $1.05 \mathrm{E}-04$ & $9.41 \mathrm{E}-05$ & 4.40E-02 & 4.20E-04 \\
\hline $\mathrm{Cr}$ & 3.97E-01 & $2.83 \mathrm{E}-03$ & $2.54 \mathrm{E}-03$ & $2.00 \mathrm{E}-02$ & $1.13 \mathrm{E}+00$ & $5.88 \mathrm{E}-02$ & $1.20 \mathrm{E}-04$ & $3.76 \mathrm{E}-03$ & $2.96 \mathrm{E}-03$ & $1.68 \mathrm{E}-01$ \\
\hline $\mathrm{Hg}$ & $3.36 \mathrm{E}-01$ & $1.40 \mathrm{E}-02$ & $2.15 \mathrm{E}-02$ & $1.69 \mathrm{E}-02$ & $9.59 \mathrm{E}-02$ & $3.63 \mathrm{E}-02$ & $2.59 \mathrm{E}-03$ & $2.32 \mathrm{E}-03$ & $1.82 \mathrm{E}-03$ & $1.04 \mathrm{E}-02$ \\
\hline $\mathrm{Pb}$ & $1.11 \mathrm{E}-02$ & 7.94E-02 & 4.11E-02 & $5.59 \mathrm{E}-04$ & $3.17 \mathrm{E}-01$ & $1.20 \mathrm{E}-02$ & $8.54 \mathrm{E}-02$ & $7.65 \mathrm{E}-03$ & $6.01 \mathrm{E}-03$ & $3.42 \mathrm{E}-02$ \\
\hline $\mathrm{Zn}$ & $2.03 \mathrm{E}-03$ & $2.45 \mathrm{E}-02$ & $1.30 \mathrm{E}-03$ & $1.02 \mathrm{E}-03$ & $5.81 \mathrm{E}-03$ & 2.19E-04 & $1.56 \mathrm{E}-02$ & $1.40 \mathrm{E}-04$ & $1.10 \mathrm{E}-04$ & $6.25 \mathrm{E}-04$ \\
\hline \multirow[t]{2}{*}{ Total hazard index } & $6.85 \mathrm{E}-01$ & $4.89 \mathrm{E}-01$ & $4.38 \mathrm{E}-01$ & $3.44 \mathrm{E}-01$ & $1.96 \mathrm{E}+00$ & $8.98 \mathrm{E}-02$ & $6.42 \mathrm{E}-02$ & $5.75 \mathrm{E}-02$ & $4.52 \mathrm{E}-02$ & $2.57 \mathrm{E}-01$ \\
\hline & \multicolumn{4}{|c|}{$\begin{array}{c}\text { Cancer risk of each heavy metals and } \\
\text { total cancer risk }\end{array}$} & & \multicolumn{4}{|c|}{$\begin{array}{c}\text { Cancer risk of each heavy metal and total } \\
\text { cancer risk }\end{array}$} & \\
\hline As & $6.30 \mathrm{E}-05$ & $4.50 \mathrm{E}-04$ & 4.03E-06 & $3.17 \mathrm{E}-05$ & $3.60 \mathrm{E}-04$ & $6.82 \mathrm{E}-06$ & $4.87 \mathrm{E}-06$ & 4.37E-06 & $3.43 \mathrm{E}-06$ & $3.90 \mathrm{E}-05$ \\
\hline $\mathrm{Cd}$ & $2.38 \mathrm{E}-10$ & $1.70 \mathrm{E}-10$ & $1.52 \mathrm{E}-10$ & $3.20 \mathrm{E}-04$ & $1.36 \mathrm{E}-09$ & $1.34 \mathrm{E}-10$ & $9.55 \mathrm{E}-11$ & $8.56 \mathrm{E}-11$ & $6.73 \mathrm{E}-11$ & $7.64 \mathrm{E}-10$ \\
\hline $\mathrm{Cr}$ & $1.09 \mathrm{E}-03$ & $4.13 \mathrm{E}-05$ & $3.70 \mathrm{E}-05$ & $2.91 \mathrm{E}-04$ & $3.31 \mathrm{E}-03$ & $6.26 \mathrm{E}-04$ & 4.47E-05 & 4.01E-05 & $3.15 \mathrm{E}-05$ & $3.58 \mathrm{E}-04$ \\
\hline $\mathrm{Hg}$ & $1.58 \mathrm{E}-08$ & $1.13 \mathrm{E}-08$ & $1.01 \mathrm{E}-08$ & 7.96E-09 & 9.04E-08 & 8.89E-09 & $6.35 \mathrm{E}-09$ & 5.69E-09 & 4.47E-09 & 5.08E-08 \\
\hline Total cancer risks & $6.42 \mathrm{E}-04$ & $4.59 \mathrm{E}-04$ & 4.11E-04 & $3.23 \mathrm{E}-04$ & $3.67 \mathrm{E}-03$ & $6.95 \mathrm{E}-05$ & $4.96 \mathrm{E}-05$ & 4.45E-05 & $3.49 \mathrm{E}-05$ & $3.97 \mathrm{E}-04$ \\
\hline
\end{tabular}


a
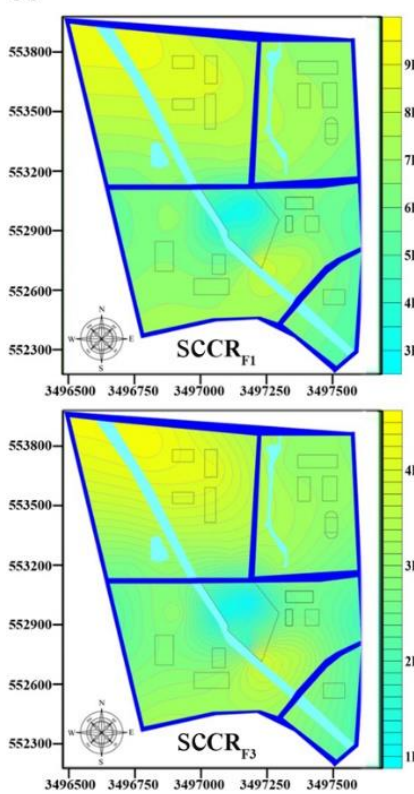
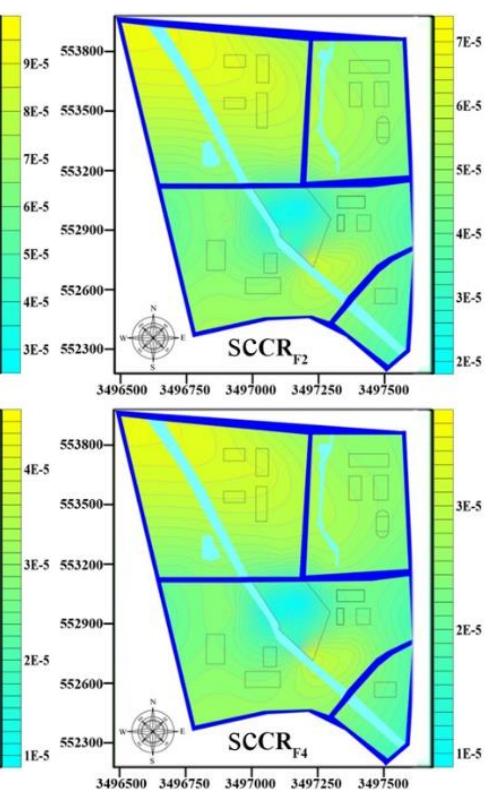

b


Fig. 6. Spatial distribution of source-contributed carcinogenic and non-carcinogenic risk assessment.

\subsection{Disscussion of the methodology}

To the traditional research, risks assessment under traceability of pollution sources was incorporated into the paper.

The evaluation model of the risk allocation of pollution sources was constructed, which was constructive for the treatment of heavy metal soil pollution. It had a certain reference value for the supplement and improvement of the health risk assessment system. The health risk assessment based on source apportionment mainly included optimized spatial interpolation and human health risk. The pollution sources were quantified for health risk assessment, which was optimized compared with conventional risk model. It turned out that the traceability results of the two sourceoriented risk assessment model were different as well as the risk contribution order of pollution sources. Sourceoriented health risk analysis was at a low risk level, which was dominated by industrial activities. Therefore, $\mathrm{Cr}$ should be regarded as the target metal, the emission of which should be converted to hypotoxic elements. It can effectively prevent pollution and realize regional environmental management. Source-oriented human health risk of As was dominated by agricultural activities. So metal arsenic should be treated as a priority target metal for soil pollution. Effective control of metal emission or lowering the concentrations of toxic element can reduce the level of health risk in this region. It was concluded that traditional health risk assessment method may overlook the source 
contributions of pollution, The traceability and contribution of certain pollution sources combined with health risk assessment could make up for these deficiencies. In the comparative study of PCA and PMF tracing, it was more reasonable to take a comprehensive source apportionment for consideration to set definite numbers for pollution sources. This study provided new insights for the treatment of complex sources and hazards of soil heavy metals.

\section{Conclusions}

It was of great significance to study the distribution of heavy metal content in abandoned factories and carry out the comprehensive health risk assessment of heavy metal, so as to provide the basis for the prevention and control of soil heavy metal pollution. The method was developed by integrating health risk assessment and source contribution based on source apportionment to study pollutant sources and risk levels. This method optimized spatial interpolation based on the global content data output so as to quantitatively analyze pollution level of the area intuitively. PCA and PMF model were arried out by auxiliary quantitative analysis on the determination of pollution sources accurately. A case study was conducted in an abandoned dye factory in Suzhou City, China, so as to implement the methodology. This study assessed spatial distribution characteristic and source-identified health risk of six heavy metals $(\mathrm{Pb}, \mathrm{Hg}$, $\mathrm{Zn}, \mathrm{Cr}, \mathrm{Cd}, \mathrm{As})$ in the study area. PMF model was utilized to apportion the sources of risk, combining a receptor model and a risk model. The source-specific human health risk of heavy metals for each source category was also discussed, in which some significant results were found. However, owing to anthropogenic influence, the area was contaminated by these heavy metals studied in some degree. Particularly, industrial activities were identified as the largest contributor by $\mathrm{Cr}$, mainly associating with the discharge and disposal of pollutants from the dye factory in the area. The results of source-contributed health risk suggested that there was potential health threat to the children. As as agriculture activities contributed most to the risk level and would lead to higher risks in the study area. After comprehensive comparison, it was concluded that in the comparative study after tracing health risks, it was more reasonable to use comprehensive site risk assessment to treat regional pollution sources in this region. This study provided a new insight for the treatment of multi-sources of heavy metal and it was advised to reduce the total 
emission in the process of industry and agriculture by regional structural reconstruction.

\section{Credit authorship contribution statement}

Fangfang miao: Data curation, Writing - original draft, Writing -review \& editing. Yimei Zhang and Yu Li, performed the guiding of this paper with support from Yinzhuang Zhou. Qinglu Fang is mainly responsible for sorting out data and assisting in drawing. We confirm that this manuscript has not been published elsewhere and is not under consideration by another journal. We affirm that all authors have approved the submission and the study does not

435 involve human and animal subjects.

\section{Declaration of Competing Interest}

The authors declare that they have no known competing financial interests or personal relationships that could

438 have appeared to influence the work reported in this paper.

\section{Data availability}

440 The datasets generated and analyzed during the current study are not publicly available due to it is confidentiality 441 but are available from the corresponding author on reasonable request.

\section{Acknowledgments}

443 This work was financially supported by the National Key R\&D Program of China (No. 2018YFB0605504) and 444 the National Natural Science Foundation of China (Grant No. 51878272). This work was supported by MOE Key 445 Laboratory of Resources and Environmental Systems Optimization (NCEPU). The authors also would like to express 446 their heartfelt gratitude to the support of NationalUniversity of Singapore Suzhou research institute. Sincere gratitude 447 should be expressed to the editors and reviewers who have put considerable time and efforts into their comments on 448 this paper.

\section{References}


Adimalla, N., Qian, H., Wang, H.K., 2019. Assessment of heavy metal (HM) contamination in agricultural soil lands in northern Telangana, India: an approach of spatial distribution and multivariate statistical analysis. Environ.Monit. Assess. 191, 246. https://doi.org/10.1007/s10661-019-7408-1.

Bryanin, S.V., Sorokina, O.A., 2019. Effect of soil properties and environmental factors on chemical compositions of forest soils in the Russian Far East. J. Soils Sediments 19, 1130-1138. https://doi.org/ 10.1007/s11368-018-2141-x.

Cai, L., Xu, Z., Bao, P., He, M., Dou, L., Chen, L., Zhou, Y., Zhu, Y.G., 2015. Multivariate and geostatistical analyses of the spatial distribution and source of arsenic and heavy metals in the agricultural soils in Shunde, Southeast China. J. Geochem.Explor. 148, 189-195. https://doi.org/10.1016/j.gexplo.2014.09.010.

Chen, H., Teng, Y., Lu, S., Wang, Y., Wang, J., 2015. Contamination features and health risk of soil heavy metals in China. Sci. Total Environ. 512, 143-153. https://doi.org/10.1016/j.scitotenv.2015.01.025.

Chen, J.Q.,Wang, Z.X.,Wu, X., Zhu, J.J., Zhou,W.B., 2011. Source and hazard identification of heavy metals in soils of Changsha based on TIN model and direct exposure method. Trans. Nonferrous Metals Soc. China 21 (3), 642-651. https://doi.org/10.1016/S1003$\underline{6326(11) 60761-9}$.

Cheng, S., Liu, G., Zhou, C., Sun R., 2018. Chemical speciation and risk assessment of cadmium in soils around a typical coal mining area of China. Ecotox. Environ. Safe. 160, 67-74. https://doi.org/10.1016/j.ecoenv.2018.05.022.

CNEPA (National Environment Protection Agency of China), 1995, Environment Quality Standard for Soils (GB 15618-1995) (in Chinese).

CSC (China State Council), 2016. The action plan for soil pollution prevention and control. Available at: http://www.gov.cn/zhengce/content/2016-05/31/content_5078377.htm (accessed in November) (in Chinese).

De Miranda, R.M., de Fatima Andrade, M., Dutra Ribeiro, F.N., Mendonça Francisco, K.J., Pérez-Martínez, P.J., 2018, Source apportionment of fine particulate matter by positive matrix factorization in the metropolitan area of São Paulo, Brazil. J. Clean Prod. 202, 253-263. https://doi.org/10.1016/j.jclepro.2018.08.100.

Dong, R.Z., Jia, Z.M., Li, S.Y., 2018. Risk assessment and sources identification of soil heavy metals in a typical county of Chongqing municipality, Southwest China. Process Saf. Environ. Prot. 113, 275-281. https://doi.org/10.1016/j.psep.2017.10.021.

Duan, J.C., Tan, J.H., Hao, J.M., Chai, F.H., 2014. Size distribution, characteristics and sources of heavy metals in haze episod in Beijing. J. Environ. Sci. 26, 189-196. https://doi.org/10.1016/S1001-0742(13)60397-6.

Duan, Y.X., Zhang, Y.M., Li, S., Fang, Q.L., Miao, F.F., Lin, Q.G., 2020, An integrated method of health risk assessment based on spatial interpolation and source apportionment. J. Clean Prod. 276. https://doi.org/10.1016/j.jclepro.2020.123218.

Franco-Uría, A., López-Mateo, C., Roca, E., Fernández-Marcos, M.L., 2009. Source identification of heavy metals in pastureland by multivariate analysis in NW Spain. J. Hazard. Mater. 165, 1008-1015. https://doi.org/10.1016/j.jhazmat.2008.10.118.

Fu, WJ., Jiang, PK., Zhou, GM., Zhao, KL.,2014. Using Moran's I and GIS to study the spatial pattern of forest litter carbon density in a subtropical region of southeastern China. Biogeosciences. 11, 2401-2409. https://doi.org/10.5194/bg-11-2401-2014. 
Gao, J., Wang, L.C., 2018. Ecological and human health risk assessments in the context of soil heavy metal pollution in a typical industrial area of Shanghai, China. Environ. Sci. Pollut. Res. 25, 27090-27105. https://doi.org/10.1007/s11356-018-2705-8.

Gholizadeh, A., Taghavi, M., Moslem, A., Neshat, A.A., Lari Najafi, M., Alahabadi, A., Ahmadi, E., Ebrahimi Aval, H., Asour, A.A., Rezaei, H., Gholami, S., Miri, M., 2019. Ecological and health risk assessment of exposure to atmospheric heavy metals. Ecotoxicol. Environ. Saf. 184, 109622. https://doi.org/10.1016/j.ecoenv.2019.109622.

Goix, S., Resongles, E., Point, D., Oliva, P., Duprey, J.L., de la Galvez, E., Ugarte, L., Huayta, C., Prunier, J., Zouiten, C., Gardon, J., 2013. Transplantation of epiphytic bioaccumulators (Tillandsia capillaris) for high spatial resolution biomonitoring of trace elements and point sources deconvolution in a complex mining/smelting urban context. Atmos. Environ. 80, 330 - 341.

Guan, Q., Wang, F., Xu, C., Pan, N., Lin, J., Zhao, R., 2018. Source apportionment of heavy metals in agricultural soil based on PMF: A case study in Hexi Corridor, northwest China. Chemosphere 193, 189-197. https://doi.org/10.1016/j.chemosphere.2017.10.151.

Guo, G., Wu, F., Xie, F., Zhang, R., 2012. Spatial distribution and pollution assessment of heavy metals in urban soils from southwest China. J Environ Sci. 24,410-418. https://doi.org/10.1016/S1001-0742(11)60762-6.

Hakanson, L., Håkanson, L., Hakansonn, L., 1980. An ecological risk index for aquatic pollution control: a sediment ecological approach. Water Res. 14, 975-1001. https://doi.org/10.1016/0043-1354(80)90143-8.

Han, Y., Du, P., Cao, J., Posmentier, E.S., 2006. Multivariate analysis of heavy metal contamination in urban dusts of Xi'an, Central China, Sci. Total Environ. 355, 176-186. https://doi.org/ 10.1016/j.scitotenv.2005.02.026.

Hu,W., Wang, H., Dong, L., Borggaard, O.K., Hansen, H.C.B., He, Y., Holm, P.E., 2018. Source identification of heavy metals in periurban agricultural soils of southeast China: an integrated approach. Environ. Pollut. 237, 650-661. https://doi.org/10.1016/j.envpol.2018.02.070.

Huang, B., Shi, X.Z., Yu, D.S., Oborn, I., Blomback, K., Pagella, T.F., Wang, H.J.,Sun, W.X., Sinclair, F.L., 2006. Environmental. assessment of small-scale vegetable farming systems in peri-urban areas of the Yangtze River Delta Region, China. Agric. Ecosyst. Environ. 112, 391-402. https://doi.org/10.1016/j.agee.2005.08.037.

Ihedioha, J.N., Ukoha, P.O., Ekere, N.R., 2017. Ecological and human health risk assessment of heavy metal contamination in soil of a municipal solid waste dump in Uyo, Nigeria. Environ. Geochem. Health 39, 497-515. https://doi.org/10.1007/s10653-016-9830-4.

Islam, S., Ahmed, K., Mamun, H.A., Eaton, D.W., 2017. Human and ecological risks of metals in soils under different land use in an urban environment of Bangladesh. Pedosphere, S1002016017603953. https://doi.org/10.1016/S1002-0160(17)60395-3.

Järup, L., 2003, Hazards of heavy metal contamination, Br. Med. Bull. 68, 167-182. https://doi.org/10.1093/bmb/ldg032.

Jia, J., Li, X., Wu, P., Liu, Y., Han, C., Zhou, L., Yang, L., 2015. Human health risk assessment and safety threshold of harmful trace elements in the soil environment of the wulantuga open-cast coal mine, Minerals 5, 0528. https://doi.org/info:doi/10.3390/min5040528. 
Jiang, F., Ren, B.Z., Hursthouse, A., Deng, R.J., Wang, Z.H., 2019. Distribution, source identification, and ecological-health risks of potentially toxic elements (PTEs) in soil of thallium mine area (southwestern Guizhou, China). Environ. Sci. Pollut. Res. 26, 1655616567. https://doi.org/10.1007/s11356-019-04997-3.

Jiang, H., Cai, L., Wen, H., Hu, G., Chen, L., Luo, J., 2019. An integrated approach to quantifying ecological and human health risks from different sources of soil heavy metals. Sci. Total Environ. 134466 https://doi.org/10.1016/j.scitotenv.2019.134466.

Kumar. V., Sharma. A., Kaur, P., Sidhu, GPS., Bali, AS., Bhardwaj, R., 2019. Pollution assessment of heavy metals in soils of India and ecological risk assessment: A state-of-the-art. Chemosphere 216, 449-462. https://doi.org/10.1016/i.chemosphere.2018.10.066.

Kurt-Karakus P B K. 2012. Determination of heavy metals in indoor dust from Istanbul, Turkey: Estimation of the health risk. Environ Int. 50, 47-55. https://doi.org/ 10.1016/j.envint.2012.09.011.

Larsen, R.K., Baker, J.E., 2003, Source apportionment of polycyclic aromatic hydrocarbons in the urban atmosphere: a comparison of three methods. Environ. Sci. Technol. 37, 1873-1881. https://doi.org/10.1021/es0206184.

Li, P., Xue, R., Wang, Y., Zhang, R., Zhang, G., 2015. Influence of anthropogenic activities on PAHs in sediments in a significant gulf of low-latitude developing regions, the Beibu Gulf, South China Sea: distribution, sources, inventory and probability risk. Mar. Pollut. Bull. 90 (1 - 2), $218-226$.

Li, Y., Chen, H., Teng, Y., 2020. Source apportionment and source-oriented risk assessment of heavy metals in the sediments of an urban river-lake system. Sci. Total Environ. 140310. https://doi.org/10.1016/j.scitotenv.2020.140310.

Liang, J., Feng, C., Zeng, G., Gao, X., Zhong, M., Li, X., 2017a. Spatial distribution and source identification of heavy metals in surface soils in a typical coal mine city, Lianyuan, China. Environ. Pollut. 225, 681-690. https://doi.org/10.1016/j.envpol.2017.03.057.

Liang, J., Feng, C., Zeng, G., Gao, X., Zhong, M., Li, X., He, X., Fang, Y., 2017b. Spatial distribution and source identification of heavy metals in surface soils in a typical coal mine city, Lianyuan, China. Environ Pollut. 225, 681-690. https://doi.o $\underline{\mathrm{rg} / 10.1016 / \mathrm{j} . \text { envpol.2017.03.057. }}$

Liu, B., Ai, S., Zhang, W., Huang, D., Zhang, Y., 2017. Assessment of the bioavailability, bioaccessibility and transfer of heavy metals in the soil-grain-human systems near a mining and smelting area in NW China. Sci. Total Environ. 609, 822-829. https://doi.org/ 10.1016/j.scitotenv.2017.07.215.

Liu, X., Ying, L., Lu, S., 2018, Occurrence of typical antibiotics and source analysis based on PCA-MLR method in the East Dongting Lake, China. Ecotox. Environ. Safe. 163, 145-152. https://doi.org/10.1016/j.ecoenv.2018.07.067.

Luo, C., Liu C., Wang, Y., Liu, X., Li, F., Zhang, G.,2011. Heavy metal contamination in soils and vegetables near an e-waste processing site, South China. J Hazard Mater. 186, 481-90. https://doi.org/10.1016/j.jhazmat.2010.11.024.

Luo, X., Xue, Y., Wang, Y., Cang, L., Xu, B., Ding, J., 2015. Source identification and apportionment of heavy metals in urban soil profiles. Chemosphere. 127, 152-157. https://doi.org/ 10.1016/j.chemosphere.2015.01.048. 
Luo X S, Yu S, Li X D. 2011. Distribution, availability, and sources of trace metals in different particle size fractions of urban soils in Hong Kong: Implications for assessing the risk to human health. Environ Pollut. 159, 1317-1326. https://doi.org/ 10.1016/j.envpol.2011.01.013.

Lv, J., Liu, Y., 2019. An integrated approach to identify quantitative sources and hazardous areas of heavy metals in soils. Sci. Total Environ. 646, 19-28. https://doi.org/10.1016/j.scitotenv.2018.07.257.

Lv, J.S., 2019. Multivariate receptor models and robust geostatistics to estimate source apportionment of heavy metals in soils. Environ. Pollut. 244, 72-83. https://doi.org/10.1016/j.scitotenv.2005.02.026.

Ma, Z., Chen, K., Li, Z., Bi, J., Huang, L., 2015. Heavy metals in soils and road dusts in the mining areas of Western Suzhou, China: a preliminary identification of contaminated sites. J SOIL SEDIMENT 16, 204-214. https://doi.org/10.1007/s11368-015-1208-1.

Mamut, A., Eziz, M., Mohammad, A., Anayit, M., 2017. The spatial distribution, contamination, and ecological risk assessment of heavy metals of farmland soils in Karashahar-Baghrash oasis, northwest China. Hum. Ecol. Risk Assess. 23, 1300-1314 https://doi.org/info:doi/10.1080/10807039.2017.1305263.

Mao, C., Song, Y., Chen, L., Ji, J., Li, J., Yuan, X., Yang, Z., Ayoko, G.A., Frost, R.L., Theiss, F.L., 2019. Human health risks of heavy metals in paddy rice based on transfer characteristics of heavy metals from soil to rice. Catena 175, 339-348. https://doi.org/10.1016/j.catena.2018.12.029.

Mendoza, C.J., Garrido, R.T., Quilodr an, R.C., Segovia, C.M., Parada, A.J., 2017. Evaluation of the bioaccessible gastric and intestinal fractions of heavy metals in contaminated soils by means of a simple bioaccessibility extraction test. Chemosphere 176, 81-88. https://doi.org/10.1016/j.chemosphere.2017.02.066.

Mohammadi, A.A., Zarei, A., Esmaeilzadeh, M., Taghavi, M., Yousefi, M., Yousefi, Z., Sedighi, F., Javan, S., 2020. Assessment of heavy metal pollution and human health risks assessment in soils around an industrial zone in Neyshabur, Iran. Biol. Trace Elem. Res. 195, 343-352. https://doi.org/10.1007/s12011-019-01816-1.

National Environmental Protection Agency (NEPA), 1995. Environmental Quality Standard for Soils (GB 15618-1995). National Environmental Protection Agency of China, Beijing.

Nazzal, Y., Howari, FM., Jafri, MK., Naeem, M., Ghrefat, H., 2016. Risk assessment through evaluation of potentially toxic metals in the surface soils of the Qassim area, Central Saudi Arabia. Ital. J. Geosci. 135, 210-216. https://doi.org/10.3301/IJG.2015.10.

Noll, M.R., 2002. Trace elements in terrestrial environments: biogeochemistry, bioavailability, and risks of metals. J. Environ. Qual. 32, 374. https://doi.org/10.2134/jeq2002.3740

Norris, G., Duvall, R., Brown, S., Bai, S., 2014. EPA Positive Matrix Factorization (PMF) 5.0 Fundamentals and User Guide. US Environmental Protection Agency, Washington, DC.

Ouyang, Z., Gao, L., Yang, C., 2018. Distribution, sources and influence factors of polycyclic aromatic hydrocarbon at different depths of the soil and sediments of two typical coal mining subsidence areas in Huainan, China. Ecotox. Environ. Safe. 163, 255-265. https://doi.org/10.1016/i.ecoenv.2018.07.024. 
Paatero, P., Tapper, U., 1994. Positive matrix factorization: a non-negative factor model with optimal utilization of error estimates of data values. Environmetrics 5, 111-126. CCC 1 180-4009/94/020 111 - 16.

Papa S, Bartoli G, Pellegrino A, Fioretto A. 2010. Microbial activities and trace element contents in an urban soil. Environ Monit Assess. 165, 193-203. https://doi.org/ 10.1007/s10661-009-0938-1.

Parra, S., Bravo, M.A., Quiroz, W., Moreno, T., Karanasiou, A., Font, O., Vidal, V., Cereceda-Balic, F., 2014. Source apportionment for contaminated soils using multivariate statistical methods. Chemom. Intell. Lab. Syst. 138, 127-132. https://doi.org/ $\underline{10.1016 / \text { i.chemolab.2014.08.003. }}$

Peng, X., Shi, G.L., Liu, G.R., Xu, J., Tian, Y.Z., Zhang, Y.F., Feng, Y.C., Russell, A.G., 2017, Source apportionment and heavy metal health risk (HMHR) quantification from sources in a southern city in China, using an ME2-HMHR method. Environ. Pollut. 221, 335-342. https://doi.org/10.1016/j.envpol.2016.11.083.

Salim, I., Sajjad, RU., Paule-Mercado, MC., Memon, SA., Lee, BY., Sukhbaatar C., 2019. Comparison of two receptor models PCAMLR and PMF for source identification and apportionment of pollution carried by runoff from catchment and sub-watershed areas with mixed land cover in South Korea. Sci Total Environ. 663, 764-775. https://doi.org/10.1016/j.scitotenv.2019.01.377.

Salmani-Ghabeshi, S., Palomo-Marín, M.R., Bernalte, E., Rueda-Holgado, F., Miró-Rodríguez, C., Cereceda-Balic, F., Fadic, X., Vidal, V., Funes, M., Pinilla-Gil, E., 2016, Spatial gradient of human health risk from exposure to trace elements and radioactive pollutants in soils at the Puchuncaví-Ventanas industrial complex, Chile. Environ. Pollut. 218, 322-330 https://doi.org/10.1016/j.envpol.2016.07.007.

Sun, L., Guo, D.K., Liu, K., Meng, H., Zheng, Y.J., Yuan, F.Q., Zhu, G.H., 2019. Levels, sources, and spatial distribution of heavy metals in soils from a typical coal industrial city of Tangshan, China. Catena 175, 101-109. https://doi.org/10.1016/j.catena.2018.12.014.

Tapia-Gatica, J., Gonzalez-Miranda, I., Salgado, E., Bravo, M.A., Tessini, C., Dovletyarova, E.A., Paltseva, A.A., Neaman, A., 2020. Advanced determination of the spatial gradient of human health risk and ecological risk from exposure to $\mathrm{As}, \mathrm{Cu}, \mathrm{Pb}$, and $\mathrm{Zn}$ in soils near the Ventanas Industrial Complex (Puchuncaví, Chile). Environ. Pollut. 258, 113488 https://doi.org/10.1016/j.envpol.2019.113488.

Teng, Y., Ni, S., Wang, J., Zuo, R., Yang, J., 2010. A geochemical survey of trace elements in agricultural and non-agricultural topsoil in Dexing area, China. Journal of Geochemical Exploration 104, 118-127.

Tian, K., Huang, B., Xing, Z., Hu, W., 2017. Geochemical baseline establishment and ecological risk evaluation of heavy metals in greenhouse soils from Dongtai, China. Ecol. Indic. 72, 510-520. https://doi.org/10.1016/j.ecolind.2016.08.037.

Tian, S., Liang, T., Li, K., Wang, L., 2018, Source and path identification of metals pollution in a mining area by PMF and rare earth element patterns in road dust. Sci. Total. Environ. 633, 958-966. https://doi.org/10.1016/j.scitotenv.2018.03.227.

USEPA (United States Environmental Protection Agency), 2014. EPA positive matrix factorization (PMF) 5.0 fundamentals and user guide. In: Norris, G., Duvall, R., Brown, S., Bai, S. (Eds.), EPA/600/R-14/108 (NTIS PB2015-105147), Washington, DC. 
Wang, S., Cai, L.M., Wen, H.H., Luo, J., Wang, Q.S., Liu, X., 2018. Spatial distribution and source apportionment of heavy metals in soil from a typical county-level city of Guangdong Province, China. Sci Total Environ. 655, 92-101. https://doi.org/ 10.1016/j.scitotenv.2018.11.244.

Wang, S., Cai, L., Wen, H., Luo, J., Wang, Q., Liu, X., 2019a. Spatial distribution and source apportionment of heavy metals in soil from a typical county-level city of Guangdong Province, China. Sci. Total. Environ. 655, 92-101. https://doi.org/10.1016/j.scitotenv.2018.11.244.

Wang, S., Hu, G., Yan, Y., Wang, S., Yu, R., Cui, J., 2019b, Source apportionment of metal elements in PM2.5 in a coastal city in Southeast China: Combined Pb-Sr-Nd isotopes with PMF method. Atmos. Environ. 198, 302-312. https://doi.org/10.1016/j.atmosenv.2018.10.056.

Wcisło, E., Bronder, J., Bubak, A., Rodríguez-Valdés, E., Gallego, J.L.R., 2016. Human health risk assessment in restoring safe and productive use of abandoned contaminated sites, Environ. Int. 94, 436-448. https://doi.org/10.1016/j.envint.2016.05.028.

Wu, Q., Leung, JYS., Geng, X., Chen, S., Huang, X., Li, H., 2015. Heavy metal contamination of soil and water in the vicinity of an abandoned e-waste recycling site: Implications for dissemination of heavy metals. Sci Total Environ. 506, 217-225. https://doi.org/ $\underline{\text { 10.1016/j.scitotenv.2014.10.121. }}$

Wu, W., Dong, C.,Wu, J., Liu, X.,Wu, Y., Chen, X., Yu, S., 2017. Ecological effects of soil properties and metal concentrations on the composition and diversity of microbial communities associated with land use patterns in an electronic waste recycling region. Sci. Total Environ. 601, 57-65. https://doi.org/10.1016/j.scitotenv.2017.05.165.

Xiao-Bo, N., X. Wen-Hua, F. Xi, Y. Wen-De, and D. Xiang-Wen, 2009, Heavy metal concentrations and pollution assessment of limestone forests in Huaxi district,Guiyang City: Acta Ecologica Sinica, v. 29, 2169-2177.

Xiao, R., Guo, D., Ali, A., Mi, S., Liu, T., Ren, C., Li, R., Zhang, Z., 2019. Accumulation, ecological-health risks assessment, and source apportionment of heavy metals in paddy soils: A case study in Hanzhong, Shaanxi, China. Environ. Prot. 248, 349-357. https://doi.org/ 10.1016/i.envpol.2019.02.045.

Xie, Z., Xiang, L., Du, Z., Jiang, Y., Zhang, H., Wu, Y., Long, T., 2016. Accumulation of heavy metals in a coastal wetland natural reserve in the estuarine wetlands of Tianjin, China. In: 2016 International Congress on Computation Algorithms in Engineering (Iccae 2016), pp. 271-280.

Xue, J., Y. Zhi, L. Yang, J. Shi, L. Zeng, and L. Wu, 2014, Positive matrix factorization as source apportionment of soil lead and cadmium around a battery plant (Changxing County, China): ENVIRON SCI POLLUT R. 21, 7698-7707.

Zhang, H., Wan, Z., Ding, M., 2018. Inherent bacterial community response to multiple heavy metals in sediment from river-lake systems in the Poyang Lake, China. Ecotox. Environ. Safe 165, 314-324. https://doi.org/10.1016/j.ecoenv.2018.09.010.

Zhang, Y., Wang, F. , Zhang, D., Chen, J., Zhu, H., Zhou, L., Chen, Z., 2017. New type multifunction porous aerogels for supercapacitors and absorbents based on cellulose nanofibers and graphene, Mater. Lett. 208 ,73-76. https://doi.org/10.1016/j.matlet.2017.04.141.

Zhang, Y., Yin, C., Cao, S., Cheng, L., Wu, G., Guo, J., 2018a, Heavy metal accumulation and health risk assessment in soil-wheat 
638 Zhang, Y., Zhang, D., Zhou, L., Zhao, Y., Chen, J., Chen, Z., Wang, F., 2018b. Polypyrrole/ reduced graphene oxide aerogel particle electrodes for high-efficiency electro-catalytic synergistic removal of $\mathrm{Cr}(\mathrm{VI})$ and bisphenol A, Chem. Eng. J. 336, 690-700. https://doi.org/ 10.1016/j.cej.2017.11.109.

641 Zhao, L., Xu, Y., Hou, H., Shangguan, Y., Li, F., 2014. Source identification and health risk assessment of metals in urban soils around the Tanggu chemical industrial district, Tianjin, China. Sci. Total Environ. 468, 654-662. https://doi.org/10.1016/j.scitotenv.2013.08.094.

644 Zhou, J., and Z. Sha, 2013, A New Spatial Interpolation Approach Based on Inverse Distance Weighting: Case Study from Interpolating Soil Properties, Communications in Computer \& Information Science, 399, 623-631. https://doi.org/10.1016/S1003-6326(11)61343-5. 


\section{Supplementary Files}

This is a list of supplementary files associated with this preprint. Click to download.

- SupplementaryMaterial.docx 